\title{
Measuring the activity of plasma membrane and vacuolar transporters in yeast
}

\author{
Melody Cools ${ }^{1}$, Maria Rompf $^{2}$, Andreas Mayer ${ }^{2}$ \& Bruno André ${ }^{1}$ \\ ${ }^{1}$ Molecular Physiology of the Cell, Universite Libre de Bruxelles (ULB), Biopark, Belgium \\ ${ }^{2}$ Department of Biochemistry, University of Lausanne (UNIL), Switzerland
}

\begin{abstract}
The yeast proteome includes about 300 polytopic membrane proteins known or predicted to function as transporters. Such proteins ensure active or passive transport of small ions or metabolites across the plasma or internal membranes. Despite decades of research on yeast transporters, many of these remain uncharacterized in terms of substrate selectivity range, subcellular localization, and biological function. Assaying the uptake of radiolabelled compounds into whole cells or isolated organelles remains a powerful method for characterizing the function and biochemical properties of these proteins. Here we describe established protocols for measuring transporter activity in whole cells, intact vacuoles, or reconstituted vacuolar vesicles. These methods have proved particularly useful in the context of our work on yeast amino acid transporters, and can in principle be applied to assaying the uptake of other categories of compounds.
\end{abstract}

Key words: Yeast membrane transporter - Yeast vacuole - Uptake assay in yeast Uptake assay

Running Head: Yeast transporters

\section{Introduction}

Assays measuring the uptake of radiolabelled compounds into cells of the yeast Saccharomyces cerevisiae have been commonly performed since the 60's, well before the advent of gene cloning and sequencing. For instance, the pioneering work of Marcelle Grenson, using uptake measurements combined with mutant isolation, established the existence of several specific amino acid permeases (Can1, Lyp1, Mup1) (1-3) and of a general amino acid permease (Gap1) (4). These uptake assays are still useful nowadays, both for characterizing the functions of orphan transporters and for studying the structure-function relationships, potential sensing function, and regulation of transporters of known function.

In yeast, transporters localized at the plasma membrane have generally been better characterized than those present in organelles (5). This is not surprising, as cell surface transporters are more readily tractable by genetic means, and it is much easier to measure transport into whole cells than into isolated compartments. Among the internal membrane transporters, those present at the vacuole have only been partially characterized. Interest in these proteins, particularly amino acid transporters, has recently been raised, as some are assumed to play an important role during autophagy (6) or in controlling the TOR kinase complex 1 (7). The activity of vacuolar transporters 
has typically been measured on either intact vacuoles (8) or reconstituted vacuolar vesicles (9). Both materials have advantages and drawbacks. Intact vacuoles still contain their sap and are thus closer to natural conditions, e. g. they may be better suited for studying exchange systems whose transport activity depends on a metabolite present in the vacuolar lumen (10). Yet because of their large size and relative fragility, they are more delicate to manipulate. Vacuolar vesicles are reconstituted from lysed intact vacuoles and they reseal right side out (11). They are smaller and thus less fragile, but have lost most of their content. This might influence the activity of some transporters. It is always possible, however, to load these vesicles with any compound of interest (12).

Here, using $\left[{ }^{14} \mathrm{C}\right]$-L-arginine transport via the Can1 permease as an example (1), we first describe a time-tested method for measuring the activity of plasma membrane uptake systems. We next describe an established method for isolating intact yeast vacuoles and converting them to vacuolar vesicles. Using $\left[{ }^{3} \mathrm{H}\right]$-L-tyrosine uptake via the Avt1 protein as an example (13), we then explain how these intact vacuoles and vacuolar vesicles can be used to measure the activity of vacuolar transporters. These methods can in principle be applied to measuring the uptake of other compounds, and should ideally be used to compare strains expressing or not the transporter of interest.

\section{Materials}

\subsection{Preparing the radiolabelled compound working solution}

1. The solution of radiolabelled compound provided by the manufacturer.

2. A concentrated solution of the same, non-radioactive compound.

3. A scintillation liquid compatible with the analysis of aqueous radioactive samples.

4. Associated scintillation vials (e. g. 20-ml translucent HDPE scintillation vials).

5. A liquid scintillation counter with associated scintillation vial racks (e.g. Beckman Coulter LS 6500 Liquid Scintillation Counter).

\subsection{Uptake assays on whole cells}

1. A 100x concentrated solution (as compared to the below-mentioned radiolabelled working solution) of the non-radiolabelled compound.

2. Filtration membranes such as nitrocellulose membrane filters $(0.45-\mu \mathrm{m}$ pore size; made of a mixture of cellulose acetate and cellulose nitrate).

3. A vacuum filter holder allowing successive filtration of multiple samples (e.g. EMD Millipore 1225 Sampling Vacuum Manifold).

4. A scintillation liquid compatible with analysis of aqueous radioactive samples.

5. Associated scintillation vials (e. g. 20-ml translucent PEHD scintillation vials).

6. A liquid scintillation counter with associated scintillation vial racks (e.g. Beckman Coulter LS 6500 Liquid Scintillation Counter).

7. Protein assay (e.g. Bradford, bicinchoninic acid) reagents 


\subsection{Preparing intact vacuoles or vacuolar vesicles}

1. 2 L of YPD: Weigh 20 g yeast extract, $20 \mathrm{~g}$ peptone, and $60 \mathrm{~g}$ dextrose. Add water to $1.8 \mathrm{l}$ and mix. Adjust to to $2 \mathrm{l}$ with water. Autoclave 2 x $1 \mathrm{l}$ YPD medium in 3-1 flasks.

2. $100 \mathrm{ml}$ of $1 \mathrm{M}$ Tris- $\mathrm{HCl}, \mathrm{pH} 8.9$ : Add $12.1 \mathrm{~g}$ to $80 \mathrm{ml}$ water. Adjust the $\mathrm{pH}$ with $\mathrm{HCl}$ and add water to $100 \mathrm{ml}$. Autoclave.

3. $20 \mathrm{ml}$ of $1 \mathrm{M}$ DTT: Weigh $3.1 \mathrm{~g}$ DTT, add it to $15 \mathrm{ml}$ water, and mix. Add water to $20 \mathrm{ml}$ and store at $-20^{\circ} \mathrm{C}$.

4. $2 \mathrm{~L}$ of $500 \mathrm{mM}$ phosphate buffer, pH 7.5 (KPi): Mix $834 \mathrm{ml}$ of $1 \mathrm{M} \mathrm{K}_{2} \mathrm{HPO}_{4}$ with $166 \mathrm{ml}$ of $1 \mathrm{M} \mathrm{KH}_{2} \mathrm{PO}_{4}$. Add $1 \mathrm{~L}$ water and autoclave.

5. $400 \mathrm{ml}$ of $4 \mathrm{M}$ sorbitol: Weigh $291.47 \mathrm{~g}$ D-sorbitol and add water to $200 \mathrm{ml}$. Mix and heat until the sorbitol is entirely dissolved. Add water to $400 \mathrm{ml}$ and autoclave.

6. $100 \mathrm{ml}$ of $20 \%$ glucose: Weigh 2 g glucose (dextrose) and add water to $80 \mathrm{ml}$. Mix, adjust to $100 \mathrm{ml}$ with water, and autoclave.

7. $200 \mathrm{ml}$ of YP $0.2 \%$ glucose: Weigh 2 g yeast extract and 2 g peptone. Add water to $160 \mathrm{ml}$ and mix. Adjust to $200 \mathrm{ml}$ with water, autoclave, and then supplement the medium with $2 \mathrm{ml}$ sterile $20 \%$ glucose (dextrose).

8. $100 \mathrm{ml}$ of $5 \mathrm{M} \mathrm{KOH}$ : Weigh $28.05 \mathrm{~g} \mathrm{KOH}$, add water to $80 \mathrm{ml}$, and mix. Adjust to $100 \mathrm{ml}$ with water.

9. $100 \mathrm{ml}$ of $500 \mathrm{mM}$ PIPES/KOH, pH 6.8: Weigh $15.12 \mathrm{~g}$ PIPES, add $50 \mathrm{ml}$ water, and mix. This makes a white milky solution. Add $5 \mathrm{M} \mathrm{KOH}$. PIPES will dissolve gradually until the solution reaches $\mathrm{pH}$ 6.8. Add water to $100 \mathrm{ml}$ and filter. Store at $4^{\circ} \mathrm{C}$.

$10.400 \mathrm{ml}$ PS buffer ( $0 \%$ Ficoll): Mix $20 \mathrm{ml}$ of $4 \mathrm{M}$ sorbitol and $8 \mathrm{ml}$ of $500 \mathrm{mM}$ PIPES/KOH, pH 6.8. Add water to $400 \mathrm{ml}$. Filter and keep at $4^{\circ} \mathrm{C}$.

11. Ficoll solutions in PS buffer (15\%, 8\%, and 4\% Ficoll):

- 15\% Ficoll: Add 60 g Ficoll 400 to $250 \mathrm{ml}$ water. Add $20 \mathrm{ml}$ of $4 \mathrm{M}$ sorbitol and 8 $\mathrm{ml}$ of $500 \mathrm{mM}$ PIPES/KOH, pH 6.8. Stir overnight at $4^{\circ} \mathrm{C}$. The next day, add water to $400 \mathrm{ml}$.

- 4\% Ficoll: Mix $108 \mathrm{ml}$ of 15\% Ficoll with $292 \mathrm{ml}$ PS buffer.

- 8\% Ficoll: Mix $212 \mathrm{ml}$ of 15\% Ficoll with $188 \mathrm{ml}$ PS buffer.

Filter all Ficoll solutions and keep them at $4^{\circ} \mathrm{C}$. Discard after 1 month.

12. Protease inhibitor cocktail (PIC) 1000x:

- Add $48 \mathrm{mg}$ Pefabloc SC to $1 \mathrm{ml}$ water.

- Add $5 \mathrm{mg}$ leupeptin to $1 \mathrm{ml}$ water.

- Add $99 \mathrm{mg}$ 0-phenanthroline to $1 \mathrm{ml}$ of $100 \%$ ethanol. Warm solution to $37^{\circ} \mathrm{C}$ to dissolve the powder.

- Add $5 \mathrm{mg}$ pepstatin A to $1 \mathrm{ml}$ of $100 \%$ methanol.

For $1 \mathrm{ml}$ of $1000 \mathrm{x}$ PIC, mix:

- $500 \mu \mathrm{l}$ Pefabloc SC solution

- $20 \mu$ leupeptin solution

- $\quad 100 \mu \mathrm{l}$ 0-phenanthroline solution

- $\quad 100 \mu \mathrm{l}$ pepstatin A solution

- $280 \mu$ l water 
Keep at $-20^{\circ} \mathrm{C}$.

13. 20x PIC: $\operatorname{mix} 20 \mu \mathrm{l} 1000 x$ PIC with $980 \mu \mathrm{l}$ water.

$14.50 \mathrm{ml}$ of $200 \mathrm{mM}$ phenylmethylsulfonyl fluoride (PMSF): Weigh $1.74 \mathrm{~g}$ PMSF, add to $40 \mathrm{ml}$ isopropanol (warm a little and stir). Add isopropanol to $50 \mathrm{ml}$.

15. DEAE-dextran solution: $2 \mathrm{mg}$ DEAE-dextran in $5 \mathrm{ml} 15 \%$ Ficoll in PS buffer. Freeze at $-20^{\circ} \mathrm{C}$.

16. $100 \mathrm{ml}$ of $1 \mathrm{M} \mathrm{MgCl}_{2}$ : Weigh $9.52 \mathrm{~g} \mathrm{MgCl}_{2}$, add water to $80 \mathrm{ml}$, and mix. Add water to $100 \mathrm{ml}$ and filter.

$17.10 \mathrm{ml}$ of $300 \mathrm{u} / \mathrm{ml}$ Zymolyase 20T: Weigh an amount of zymolyase corresponding to 3000 units and add $9 \mathrm{ml}$ water. Mix and add water to $10 \mathrm{ml}$.

18. P1000 and P200 automatic pipettes.

19. P200 pipette tips cut to a 1-2-mm hole diameter.

20. P1000 pipette tips cut to a 4-5-mm hole diameter.

21. An ice bucket.

22. An SW41-Ti Beckman Coulter swinging rotor and an SW55-Ti Beckman Coulter swinging rotor, their respective compatible tubes, and a compatible ultracentrifuge.

23. 500- $\mathrm{ml}$ bottles ( 6 per rotor) and a compatible centrifuge and rotor (e. g. a Sorvall RC-5B with a GS-3 rotor).

24.50-ml conical polypropylene Falcon tubes (6 per rotor) and a compatible centrifuge (e. g. a 5810R Eppendorf centrifuge with an A-4-62 rotor).

25. A $29^{\circ} \mathrm{C}$ water bath.

26. Protein assay (e.g. Bradford, bicinchoninic acid) reagents.

\subsection{Uptake assays on intact vacuoles/vacuolar vesicles}

1. $100 \mathrm{mM}$ ATP: Weigh $60.5 \mathrm{mg}$ ATP and dissolve in $100 \mu \mathrm{l}$ of $1 \mathrm{M} \mathrm{MgCl}_{2}, 100 \mu \mathrm{l}$ of $500 \mathrm{mM}$ PIPES/KOH pH 6.8, $42 \mu \mathrm{l}$ of $5 \mathrm{M} \mathrm{KOH}$, and $758 \mu \mathrm{l} \mathrm{H}_{2} 0$. Keep at $-20^{\circ} \mathrm{C}$.

2. 20x PIC: $\operatorname{mix} 20 \mu \mathrm{l} 1000 x$ PIC with $980 \mu \mathrm{l}$ water.

3. $100 \mathrm{ml}$ of $100 \mathrm{mM} \mathrm{MgCl}_{2}$ : Weigh $0.95 \mathrm{~g} \mathrm{MgCl}_{2}$, add water to $80 \mathrm{ml}$, and mix. Add water to $100 \mathrm{ml}$ and filter.

4. $100 \mathrm{ml}$ of $2 \mathrm{M} \mathrm{KCl}$ : Weigh $14.91 \mathrm{~g} \mathrm{KCl}$ and add $85 \mathrm{ml}$ water. Mix, add water to 100 $\mathrm{ml}$, and filter.

5. The solution of radiolabelled compound provided by the manufacturer.

6. A $27^{\circ} \mathrm{C}$ water bath

7. $40 \mathrm{ml}$ cold stop buffer: Mix $2 \mathrm{ml}$ of $4 \mathrm{M}$ sorbitol, $800 \mu \mathrm{l}$ of $500 \mathrm{mM}$ PIPES/KOH, $\mathrm{pH}$ $6.8,1.6 \mathrm{ml}$ of $100 \mathrm{mM} \mathrm{MgCl}, 3 \mathrm{ml}$ of $2 \mathrm{M} \mathrm{KCl}, 40 \mu \mathrm{l} 1000 x$ PIC. Add water to $40 \mathrm{ml}$. Keep at $4^{\circ} \mathrm{C}$.

8. A scintillation liquid compatible with analysis of aqueous radioactive samples.

9. Associated scintillation vials (e.g. 20-ml translucent PEHD scintillation vials)

10. A liquid scintillation counter with associated scintillation vial racks (e.g. Beckman Coulter LS 6500 Liquid Scintillation Counter).

For the centrifugation method:

11. Cool the centrifuge and rotor for 1.5- or 2.0-ml tubes (e.g. an Eppendorf 5425R centrifuge with an FA 54-24-11 rotor).

For the filtration method:

12. Filtration membranes such as nitrocellulose membrane filters $(0.45-\mu \mathrm{m}$ pore size; made of a mixture of cellulose acetate and cellulose nitrate). 
13. A vacuum filter holder allowing simultaneous filtration of multiple samples (e.g. EMD Millipore 1225 Sampling Vacuum Manifold).

\section{Methods}

\subsection{Preparing the radiolabelled compound working solution}

1. Estimate the required volume $(V, \mathrm{ml})$, concentration $(\mathrm{C})$, and specific activity $(\mathrm{mCi} / \mathrm{mmol})$ of the solution [see Note 1]

2. Mix volume $v 1$ of radiolabelled compound solution with volume $v 2$ of cold compound solution in volume $v 3$ of solvent (generally water) $(v 1+v 2+v 3=V)$ [see Note 2]

3. Add a sample $(v$, e.g. $10 \mu \mathrm{l})$ of this radiolabelled compound working solution to each of several vials containing scintillation fluid (e.g. $5 \mathrm{ml}$ ) and measure the average cpm

4. Calculate the measured specific activity of the solution ( $\mathrm{SA}, \mathrm{cpm} / \mu \mathrm{mol})$, using the following formula:

$$
S A(c p m / \mu \mathrm{mol})=\frac{\text { average cpm }}{C(\mu \mathrm{mol} / \mu \mathrm{l}) \cdot v(\mu \mathrm{l})}
$$

\subsection{Yeast cultures and determining the protein constant $(P)$}

For optimal reproducibility of uptake measurements on whole cells or isolated vacuoles, it is recommended to carefully prepare yeast cultures according to the classic procedure described below. This procedure yields exponentially growing cells which, ideally, are in a state of balanced growth (14).

1. Inoculate a preculture (e.g. $20 \mathrm{ml}$ ) with a small sample of cells freshly replicated on a Petri dish. Also prepare a flask containing a larger volume (e.g. $100 \mathrm{ml}$ ) of the same culture medium. Incubate the preculture and culture flasks overnight at $30^{\circ} \mathrm{C}$ with rotation.

2. The next day, measure the OD of the preculture. If needed, estimate the doubling time during exponential growth. Inoculate the culture with a volume of preculture calculated so as to reach the desired OD at the desired time the next day.

3. The next day, the culture can be used to determine the protein constant (P). For this, use an appropriate method (e.g. Bradford protein assay or bicinchoninic acid assay) to measure the total amount of protein (T) associated with a volume (V) of culture at a given OD (at 660 or $600 \mathrm{~nm}$ ) during the exponential growth phase. The ratio of the measured amount of protein to the OD is $\mathrm{P}$, the protein constant, needed to calculate uptake rates [See Note 3]:

$$
P\left(m g \text { protein. } m l^{-1} . O D^{-1}\right)=\frac{T(m g \text { protein })}{O D . V(m l)}
$$




\subsection{Uptake assays on whole cells}

The protocol described below has been adapted from the method originally developed by M. Grenson and collaborators (1).

1. Place the required number of filters on the holder, engage the vacuum for filtration, and saturate the filters with $3 \mathrm{ml}$ of $100 \mathrm{x}$ concentrated solution of nonradiolabelled compound.

2. Measure the OD of the culture of exponentially growing cells and transfer a sample (e.g. $5 \mathrm{ml}$ ) to a prewarmed flask

3. Add one volume of radiolabelled compound working solution to the culture sample [See Note 4], gently shake the culture.

4. After the chosen uptake time [See Note 5], sample a volume of culture $(v c)$ (usually $1 \mathrm{ml}$ ) and filter it. Immediately rinse the filter twice with iced water.

5. Repeat step 4 for every chosen time point of the uptake period.

6. Transfer the filters to scintillation vials. These must be filled with enough scintillation liquid to totally immerse the filters. Measure the cpm in a scintillation counter.

7. Measure the background radioactivity left on a filter after filtering a sample $(v c)$ of growth medium (without cells) to which an equivalent amount of radiolabelled compound working solution has been added. First presaturate the filter as described above.

8. Using the OD measured at the start of the experiment, calculate the amount of protein engaged in the assay:

$$
m g \text { protein }=O D \cdot v c(m l) \cdot P\left(m g \text { protein } \cdot m^{-1} \cdot O D^{-1}\right)
$$

where $\mathrm{P}$ is the protein constant measured beforehand.

Using the measured cpm, calculate the amount of accumulated compound for each time point:

$$
\text { accumulated compound (nmol.mg protein } \left.{ }^{-1}\right)=\frac{c p m \cdot \frac{1}{S A\left(\text { cpm.nmol }^{-1}\right)}}{m g \text { protein }}
$$

where $S A$ is the measured specific activity of the radiolabelled compound working solution, and $\mathrm{mg}$ protein is the amount of protein calculated above. Plot the calculated values as a function of time and deduce the uptake rate (nmol.mg protein $^{-1} . \mathrm{min}^{-1}$ ) from the slope (Fig. 1). Do not forget to subtract any background cpm measured beforehand. When one proceeds in this manner, the slope should pass through the origin of the nmol.mg protein $^{-1}$ and uptake time axes.

\subsection{Preparing intact vacuoles/vacuolar vesicles}

The method described below has been adapted from those described in several previous reports (15-18). It has been optimized for a large volume of cell culture $(2 \times 1 \mathrm{~L})$ in YPD medium [see Note 6]. 
1. Prepare $300 \mathrm{ml}$ Tris buffer per rotor: mix $9 \mathrm{ml}$ of $1 \mathrm{M}$ Tris- $\mathrm{HCl}, \mathrm{pH} 8.9$ stock solution with $291 \mathrm{ml}$ water.

2. When the cultures have reached the desired OD [see Note 6], split them into centrifugation bottles and centrifuge them for 6 minutes at 3,200 $\mathrm{g}$ at room temperature. Resuspend the cells in Tris buffer (25 ml/bottle) and transfer them to $50-\mathrm{ml}$ Falcon tubes (6 tubes/rotor). Make sure there are no cell clumps remaining. Add $250 \mu \mathrm{l}$ of $1 \mathrm{M}$ DTT to each Falcon tube and incubate for 10 minutes at $29^{\circ} \mathrm{C}$. Centrifuge for 5 minutes at $3,200 \mathrm{~g}$ at room temperature.

3. Meanwhile, prepare $100 \mathrm{ml}$ fresh spheroplasting buffer: mix $15 \mathrm{ml}$ of $4 \mathrm{M}$ sorbitol and $10 \mathrm{ml}$ of $500 \mathrm{mM} \mathrm{Kpi,pH} 7.5$ with $75 \mathrm{ml}$ YP medium containing $0.2 \%$ glucose [see Note 7]. Mix well and decant $7.4 \mathrm{ml}$ of buffer. Fill up again with $7.4 \mathrm{ml}$ zymolyase solution $(300 \mathrm{u} / \mathrm{ml}$ ) [see Note 8] and $500 \mu \mathrm{l}$ of $200 \mathrm{mM}$ PMSF [see Note 9]. Mix again.

4. Spheroplasting step: Resuspend each pellet in $15 \mathrm{ml}$ spheroplasting buffer. Incubate for $30 \mathrm{~min}$ in a $30^{\circ} \mathrm{C}$ water bath. After $15 \mathrm{~min}$ of incubation, add again 75 $\mu \mathrm{l}$ of $200 \mathrm{mM}$ PMSF to each tube [see Notes 8 and 9] and mix gently.

5. Just before use, supplement Ficoll buffers as follows [see Note 8]:

- $15 \mathrm{ml} \mathrm{0 \%} \mathrm{Ficoll} \mathrm{with} 15 \mu \mathrm{l}$ PIC $1000 \mathrm{x}$ and $75 \mu \mathrm{l}$ of $1 \mathrm{M} \mathrm{MgCl}_{2}$ [see Note 10]

- $\quad 30 \mathrm{ml} 4 \%$ Ficoll with $30 \mu \mathrm{l}$ PIC $1000 \mathrm{x}$ and $15 \mu \mathrm{l}$ of $1 \mathrm{M} \mathrm{MgCl}_{2}$

- $\quad 30 \mathrm{ml} 8 \%$ Ficoll with $30 \mu \mathrm{l}$ PIC $1000 \mathrm{x}$ and $15 \mu \mathrm{l}$ of $1 \mathrm{M} \mathrm{MgCl}_{2}$

- $15 \mathrm{ml} 15 \%$ Ficoll with $15 \mu \mathrm{l}$ PIC $1000 \mathrm{x}$ and $15 \mu \mathrm{l}$ of $100 \mathrm{mM} \mathrm{MgCl}_{2}$

6. Centrifuge the spheroplasts at $3,200 \mathrm{~g}$ for 5 minutes at $4^{\circ} \mathrm{C}$. Carefully decant the supernatant without losing the pellet.

7. Cell lysis step: Place tubes on ice. Add $2 \mathrm{ml}$ of $15 \%$ Ficoll. Resuspend gently, using a P1000 automatic pipette with cut tips or by brief gentle vortexing. Add $250 \mu \mathrm{l}$ DEAE-dextran and gently mix again. Incubate on ice for $2 \mathrm{~min}$ and then at $29^{\circ} \mathrm{C}$ for 2 min.

8. Lay the gradient: Transfer lysed cells to the bottoms of SW41-compatible tubes. Overlay with $4 \mathrm{ml} \mathrm{8 \%} \mathrm{Ficoll} \mathrm{and} 4 \mathrm{ml}$ 4\% Ficoll (in this order), using a P1000 automatic pipette and cut tips. Fill tubes to the top with $2 \mathrm{ml} 0 \%$ Ficoll as last layer. Place SW41 tubes in rotor cups and equilibrate weights. Proceed carefully so as not to disturb the gradients.

9. Ultracentrifugation: $30,000 \mathrm{rpm}$ (about $150,000 \mathrm{~g}$ ) for $90 \mathrm{~min}$ at $4^{\circ} \mathrm{C}$. The centrifugation time can be increased for strains with a low yield. A longer spin, however, may lead to contamination with other organelles.

10. Harvest the vacuoles: Suck off any lipid layer at the top of the tubes, using a yellow cut tip. Pipet the vacuoles from the 0-4\% interface, using a 200- $\mu$ l automatic pipet with cut tips and pool them in a 2-ml Eppendorf tube. Keep the samples on ice.

If you wish to carry out uptake assays on intact vacuoles, skip step 11. Otherwise, proceed to vacuole lysis.

11. Vacuole lysis. First, prepare lysis solutions:

- $10 \mathrm{ml} 1 \mathrm{x}$ lysis solution: Mix $500 \mu \mathrm{l} 20 \mathrm{x}$ PIC, $200 \mu \mathrm{l}$ of $500 \mathrm{mM}$ PIPES/KOH, pH 6.8 , and $9.3 \mathrm{ml}$ water.

- 10 ml 2x lysis solution: Mix $500 \mu \mathrm{l}$ 20x PIC, $400 \mu \mathrm{l}$ of 500 mM PIPES/KOH, pH 6.8, and $9.1 \mathrm{ml}$ water.

To 1 volume of vacuole sample add 1 volume of $2 x$ lysis solution and 2 volumes of $1 \mathrm{x}$ lysis solution. Mix with a $1000 \mu \mathrm{l}$ automatic pipette. Centrifuge at 16,000 g and 
$4^{\circ} \mathrm{C}$ for 10 minutes. Discard the supernatant and resuspend the vacuolar vesicles in $1 / 2$ volume of $0 \%$ Ficoll solution supplemented with 1x PIC. Keep samples on ice.

12. Measure the total protein concentration of each vacuole or vacuolar vesicle sample (using, e.g., the Bradford or the bicinchoninic acid assay). It is expected to range between 0.2 and $1 \mathrm{mg} / \mathrm{ml}$.

\subsection{Uptake assays on intact vacuoles/vacuolar vesicles}

The uptake assay must be carried out as soon as possible (ideally, less than 2 hours) after preparation of the vacuoles or vacuolar vesicles. Table 1 shows the final composition of the reaction mix with, for each ingredient, the volume to be added to obtain a final volume of $100 \mu \mathrm{l}$ per tube.

1. Mix the $2 \mathrm{M} \mathrm{KCl}, 100 \mathrm{mM} \mathrm{MgCl}_{2}$, and 20x PIC solutions in the proportions indicated in Table 1, so as to obtain enough solution for the desired number of assays. Keep this mix on ice.

\begin{tabular}{|l|c|c|}
\hline \multicolumn{3}{|l|}{ Table 1. Composition of the uptake assay mix for vacuolar vesicles and intact vacuoles. } \\
\hline Solution & Volume $(\boldsymbol{\mu l})$ & $\begin{array}{c}\text { Final } \\
\text { concentration }\end{array}$ \\
\hline $2 \mathrm{M} \mathrm{KCl}$ & 7.5 & $150 \mathrm{mM}$ \\
\hline $100 \mathrm{mM} \mathrm{MgCl}{ }_{2}$ & 4 & $4 \mathrm{mM}$ \\
\hline $20 \mathrm{x}$ PIC & 5 & $1 \mathrm{x}$ \\
\hline Optional : & & 4 \\
\hline $100 \mathrm{mM}$ ATP & & $4 \mathrm{mM}$ \\
\hline V-ATPase inhibitor (e.g. bafilomycin) & & $6.5 \mu \mathrm{M}$ \\
\hline Ionophore (e.g. FCCP) & & $6.5 \mu \mathrm{M}$ \\
\hline & & $\begin{array}{c}\text { Depends on the } \\
\text { assay (see Notes } \\
\mathbf{1} \text { and 2] }\end{array}$ \\
\hline Radiolabelled compound working solution & & $\begin{array}{c}\text { Equivalent of 20- } \\
40 \mu \mathrm{g} \text { proteins }\end{array}$ \\
\hline Vacuoles or vacuolar vesicles & & to $100 \mu \mathrm{l}$ \\
\hline $0 \%$ Ficoll solution & & \\
\hline
\end{tabular}

2. Prepare a tube $(1.5-2 \mathrm{ml})$ for each time point of each transport assay. In each tube, place the desired optional compound or an equivalent volume of $0 \%$ Ficoll as a control (see quantities in Table 1).

3. Add vesicles/vacuoles to the mix prepared in point 1 and divide the resulting mixture among the tubes.

4. Incubate the tubes for $8 \mathrm{~min}$ in a water bath $\left(27^{\circ} \mathrm{C}\right)$. 
5. Add the radiolabelled compound to each tube to start the transport reaction. Incubate each tube for the desired time.

6. Stop the transport reaction by adding $500 \mu \mathrm{l}$ ice-cold stop buffer.

7. If intact vacuoles are used:

- Centrifuge the samples for $5 \mathrm{~min}$ at 2,500 g.

- Discard the supernatants and wash the vacuole pellets with $500 \mu$ ice-cold stop buffer.

- Centrifuge for $3 \mathrm{~min}$ at $16,000 \mathrm{~g}$.

- Discard the supernatants, resuspend the pellets in $1 \mathrm{ml}$ scintillation liquid, and measure the cpm in a scintillation counter.

If vacuolar vesicles are used:

- Apply the filtration method as detailed for uptake into whole cells (Method 3.3 , points 4 to 7 ) or the centrifugation method as described above for intact vacuoles [see Note 11] and measure the cpm in a scintillation counter.

8. To estimate the background when the filtration method is used, cpm are averaged over several additional tube reactions including all components but the vacuoles/vacuolar vesicles. If the centrifugation method is used, determine the background by measuring the average cpm of reaction tubes to which the radiolabelled solution was not added to start the reaction, but with the stop buffer.

9. After subtracting the background cpm, calculate for each time point the amount of accumulated compound:

$$
\text { accumulated compound (nmol.mg protein } \left.{ }^{-1}\right)=\frac{c p m \cdot \frac{1}{S A\left(\text { cpm.nmol }^{-1}\right)}}{m g \text { protein }}
$$

where $m g$ protein is the amount of protein engaged in the assay, and $S A$ is the measured specific activity of the radiolabelled compound working solution. Plot the calculated values as a function of time and deduce the uptake rate (nmol.mg protein $^{-1} \cdot \mathrm{min}^{-1}$ ) from the slope (Fig. 2).

\section{Notes}

1. The radiolabelled compound must be handled in strict compliance with the safety rules applicable in the work environment. If the level of the transport activity to be measured is unknown, it is preferable to prepare initially a radiolabelled working solution with a high specific activity $(\mathrm{mCi} / \mathrm{mmol})$. Once first uptake measurements have been carried out, the radiolabelled solution (or a sample thereof) can be mixed with the non-radioactive solution (same concentration) to reduce its specific activity while ensuring the unaltered sensitivity of the transport assay. This also reduces the cost of the experiment and the background, and handling radioactive solutions with lower specific activities is safer. The concentration of the radiolabelled working solution should be determined 
according to the apparent affinity constant $(\mathrm{Km})$ of the transport activity/transporter of interest. A common way to proceed is to use a concentration close to saturation (e.g. 10 - to 20 -fold the $\mathrm{Km}$ value) so that the maximal activity of the transporter (close to Vmax) under the tested conditions is measured, and the sensitivity of the assay is optimal. Another option is to use a concentration corresponding to the $\mathrm{Km}$ (half-saturating), which reduces the cost of the experiment and can also be advantageous when the compound enters cells via additional, lower-affinity systems. In the latter situation, specific mutants deficient for the interfering transporters can also be used, when available. When the $K m$ value is unknown, it is recommended to initially prepare a small amount of highly concentrated solution (e.g. $200 \mathrm{mM}$ for a 100x concentrated solution) and to carry out uptake assays with decreasing concentrations. The concentrated radiolabelled solution can then be diluted with water to adjust it to an optimal concentration.

2. The manufacturer specifies the total activity of the radioactive solution ( $\mathrm{mCi}$ ), the activity concentration of the compound $(\mathrm{mCi} / \mathrm{ml})$, and its specific activity ( $\mathrm{mCi} / \mathrm{mmol}$ ). An additional value must be determined on a sample of the solution: the cpm/Ci ratio, which is specific to the scintillation counter and to the radioactive isotope used. To prepare the working solution of radiolabelled compound (e.g. 50-100-fold concentrated), a sample of the radioactive solution is mixed with a sample of a solution of cold compound in the solvent used (usually water). For instance, a manufacturer might supply $0.5 \mathrm{ml}$ of a ${ }^{14} \mathrm{C}$-labelled amino acid with the following specifications: $50 \mu \mathrm{Ci}, 0.1 \mathrm{mCi} / \mathrm{ml}, 338 \mathrm{mCi} / \mathrm{mmol}$. The concentration of the compound in the radioactive solution is usually very low and can be disregarded. If the cpm/Ci ratio is $2,500,000 \mathrm{cpm} / \mu \mathrm{Ci}$ and one needs to prepare $5 \mathrm{ml}$ of a $10 \mathrm{mM}$ solution of an amino acid at a specific activity of 150,000 $\mathrm{cpm} / \mu \mathrm{mol}$ (appropriate for measuring the activity of a highly active amino acid permease at the yeast plasma membrane), the radioactive working solution is prepared by mixing $30 \mu \mathrm{l}$ of radioactive solution with $250 \mu \mathrm{l}$ of a cold amino acid solution $(0.2 \mathrm{M})$ in $4.72 \mathrm{ml}$ water. Samples of working solution are then used to determine its actual specific activity ( $\mathrm{Ci} / \mu \mathrm{mol})$ to be used in calculations. To measure the activity of a vacuolar amino acid permease, which is usually substantially lower, the specific activity may have to be much (10- to 100-fold) higher.

3. The protein constant $P$ will vary according to the yeast background strain, the growth conditions, the method used to measure the amount of protein, the wavelength at which the OD is measured, and the spectrophotometer used to measure the OD.

4. Direct addition of the radiolabelled solution to a culture sample is applicable only if no compound in the growth medium interferes competitively with uptake. Otherwise, first filter a sample of the culture, wash it and resuspend it in the same volume of prewarmed buffer (e.g. $0.1 \mathrm{M}$ phosphate buffer adjusted to $\mathrm{pH}$ 6.5) or minimal medium before adding the radiolabelled compound. The additional presence of glucose $(0.2 \%)$ in the resuspension buffer or medium is needed to maintain the $\mathrm{H}^{+}$gradient at the plasma membrane, which is crucial for measuring the activity of secondary active transporters (19).

5. As when measuring the activity of an enzyme, transmembrane transport must be monitored during short time intervals (e.g. a few minutes) within which the compound enters cells at a constant rate. Too-long incubation times often result 
in loss of linear uptake due to regulatory effects or exhaustion of the radiolabelled substrate.

6. The vacuole isolation method described here has been optimized for yeast cells grown on YPD complete medium. We usually collect cells when cultures reach the end of the logarithmic growth phase $\left(8.10^{6}\right.$ cells $\left./ \mathrm{ml}\right)$ in order to maximize the yield of the vacuole preparations. Vacuoles can also be isolated from cells grown on a minimal medium. This, in our hands, allows higher reproducibility of uptake measurements. It is then recommended to adapt the OD of the culture at which the cells are collected (as this step must be carried out during exponential growth) as well as the amount of zymolyase and DEAE-dextran used (as the efficiency of cell wall digestion tends to vary according to the cell growth rate and culture medium).

7. The presence of glucose during the spheroplasting step is essential to the preparation, as glucose starvation has been shown to lead to disassembly of the V-ATPase (20).

8. The optimal zymolyase concentration needed to generate spheroplasts can vary substantially according to the yeast strain and growth medium. It is thus recommended to calibrate this concentration prior to launching vacuole isolation. To monitor spheroplast formation, dilute $15-\mu \mathrm{l}$ samples of spheroplasting reaction mixture in $1 \mathrm{ml}$ water and measure the gradual OD $_{660}$ decrease. Under optimal conditions, $90 \%$ of the initial OD is lost after $30 \mathrm{~min}$.

9. PIC and PMSF can be omitted if you are working with vacuolar-protease-deficient strains (18).

10. The presence of magnesium ion during the preparation of intact vacuoles has been shown to be essential to measure vacuolar uptake activity (21).

11. Intact vacuoles tend to break when filtered, so it is necessary to use a centrifugation method to collect them. This approach can also be used to collect vacuolar vesicles.

\section{Acknowledgements}

We thank Christos Gournas, Stephan Vissers, and Kathleen Broman for critical reading of the manuscript. M.C. was the recipient of a FRIA PhD fellowship. This work was supported by a PDR grant (nr. 23655065) from the FNRS (Fédération WallonieBruxelles, Belgium) and by a grant from the Cystinosis Research Foundation.

\section{References}

1. Grenson, M., Mousset, M., Wiame, J. M., and Béchet, J. (1966) Multiplicity of the amino acid permeases in Saccharomyces cerevisiae. I. Evidence for a specific arginine-transporting system. Biochim. Biophys. Acta. 127, 325-338

2. Grenson, M. (1966) Multiplicity of the amino acid permeases in Saccharomyces cerevisiae. II. Evidence for a specific lysine-transporting system. Biochim. Biophys. Acta. 127, 339-346

3. Gits, J. J., and Grenson, M. (1967) Multiplicity of the amino acid permeases in Saccharomyces cerevisiae. 3. Evidence for a specific methionine-transporting system. Biochim. Biophys. Acta. 135, 507-516

4. Grenson, M., Hou, C., and Crabeel, M. (1970) Multiplicity of the amino acid 
permeases in Saccharomyces cerevisiae. IV. Evidence for a general amino acid permease. J. Bacteriol. 103, 770-777

5. Van Belle, D., and André, B. (2001) A genomic view of yeast membrane transporters. Curr. Opin. Cell Biol. 13, 389-398

6. Yang, Z., Huang, J., Geng, J., Nair, U., and Klionsky, D. J. (2006) Atg22 recycles amino acids to link the degradative and recycling functions of autophagy. Mol. Biol. Cell. 17, 5094-5104

7. Nicastro, R., Sardu, A., Panchaud, N., and De Virgilio, C. (2017) The Architecture of the Rag GTPase Signaling Network. Biomolecules. 7, 48

8. Boller, T., Dürr, M., and Wiemken, A. (1975) Characterization of a specific transport system for arginine in isolated yeast vacuoles. Eur. J. Biochem. 54, 81-91

9. Ohsumi, Y., and Anraku, Y. (1981) Active transport of basic amino acids driven by a proton motive force in vacuolar membrane vesicles of Saccharomyces cerevisiae. J. Biol. Chem. 256, 2079-2082

10. Boller, T., Dürr, M., and Wiemken, A. (1989) Transport in isolated yeast vacuoles: characterization of arginine permease. Meth. Enzymol. 174, 504-518

11. Kakinuma, Y., Ohsumi, Y., and Anraku, Y. (1981) Properties of H+-translocating adenosine triphosphatase in vacuolar membranes of SAccharomyces cerevisiae. J. Biol. Chem. 256, 10859-10863

12. Sato, T., Ohsumi, Y., and Anraku, Y. (1984) An arginine/histidine exchange transport system in vacuolar-membrane vesicles of Saccharomyces cerevisiae. J. Biol. Chem. 259, 11509-11511

13. Russnak, R., Konczal, D., and McIntire, S. L. (2001) A family of yeast proteins mediating bidirectional vacuolar amino acid transport. J. Biol. Chem. 276, 2384923857

14. Wiame, J. M., Grenson, M., and Arst, H. N. (1985) Nitrogen catabolite repression in yeasts and filamentous fungi. Adv. Microb. Physiol. 26, 1-88

15. Wiemken, A. (1975) Isolation of vacuoles from yeasts. Methods Cell Biol. 12, 99109

16. Stevens, T., Esmon, B., and Schekman, R. (1982) Early stages in the yeast secretory pathway are required for transport of carboxypeptidase $Y$ to the vacuole. Cell. $\mathbf{3 0}$, 439-448

17. Conradt, B., Shaw, J., Vida, T., Emr, S., and Wickner, W. (1992) In vitro reactions of vacuole inheritance in Saccharomyces cerevisiae. J. Cell Biol. 119, 1469-1479

18. Gerasimaite, R., Sharma, S., Desfougères, Y., Schmidt, A., and Mayer, A. (2014) Coupled synthesis and translocation restrains polyphosphate to acidocalcisomelike vacuoles and prevents its toxicity. J Cell Sci. 127, 5093-5104

19. Serrano, R. (1983) In vivo glucose activation of the yeast plasma membrane ATPase. FEBS Lett. 156, 11-14

20. Kane, P. M. (1995) Disassembly and reassembly of the yeast vacuolar H(+)-ATPase in vivo. J. Biol. Chem. 270, 17025-17032

21. Ohsumi, Y., and Anraku, Y. (1981) Active transport of basic amino acids driven by a proton motive force in vacuolar membrane vesicles of Saccharomyces cerevisiae. J. Biol. Chem. 256, 2079-2082. 


\section{Figure legends}

Figure 1. Uptake of $\left[{ }^{14} \mathrm{C}\right]$-L-Arginine $(100 \mu \mathrm{M})$ by a wild-type strain (WT) and a can1 $\Delta$ mutant lacking the arginine-specific permease. Cells were grown on a minimal glucose medium containing $\mathrm{NH}_{4}+(50 \mathrm{mM})$ as sole nitrogen source. Values are means of three biological replicates, error bars correspond to standard deviation.

Figure 2. Uptake of $\left[{ }^{3} \mathrm{H}\right]$-L-Tyrosine $(50 \mu \mathrm{M})$ into vacuolar vesicles prepared from a wild-type (WT) and an avt1ム mutant strain grown on a minimal glucose medium containing $\mathrm{NH}_{4}{ }^{+}(20 \mathrm{mM})$ as sole nitrogen source. Values are means of two biological replicates, error bars correspond to standard deviation. 